\title{
Antiphospholipid syndrome and retinal vein occlusion
}

\author{
Sindrome do anticorpo antifosfolípide \\ e oclusão venosa retiniana
}

Alinne Maria Camargos da Costa ${ }^{1}$ Homero Gusmão de Almeida², Christian Marcellus de Camargo Campos³, Roberto Martins Gonçalves ${ }^{3}$

\begin{abstract}
A 34-year-old white man presented with a sudden unilateral recurrent visual loss. Fundus examination and fluorescein angiography revealed severe retinal vein occlusion. An antiphospholipid syndrome was discovered during etiological check up. A mutation of Leiden $\mathrm{V}$ factor was discovered and the patient started long term anticoagulation after the second occlusive event. However, secondary neovascular glaucoma has developed and despite treatment the affected eye had an important reduction of visual acuity. The purpose of this case report is to demonstrate that retinal vascular occlusion can be the initial manifestation of the antiphospholipid syndrome and that its diagnosis is important because this disease generally affects young people and may endanger ocular and vital prognosis. This diagnosis may imply a long lasting anticoagulative or antiaggregative treatment to reduce the risk of recurrent thrombotic events.
\end{abstract}

Keywords: Retinal vein occlusion; Antiphospholipid syndrome; Glaucoma; Case reports

\footnotetext{
'Clinical Assistant Ophthalmologist, Departament of Cataract and Glaucoma, Instituto de Olhos de Belo Horizonte (MG), Brazil;

2 Professor of Ophthalmology, Universidade Federal de Minas Gerais - UFMG - Belo Horizonte (MG), Brazil;

${ }^{3}$ Post-Graduated in Ophthalmology, Universidade Federal de Minas Gerais - UFMG - Belo Horizonte (MG), Brazil.
}

Institution: Instituto de Olhos de Belo Horizonte (MG), Brazil.

Recebido para publicação em: 19/9/2008 - Aceito para publicação em 13/4/2009 


\section{INTRODUCTION}

A ntiphospholipid syndrome is characterized by the production of antiphospholipid antibodies associated with thrombotic phenomena, most commonly in patients with other underlying autoimmune diseases. If these antibodies are present in the absence of another recognizable autoimmune disease, however, the syndrome is known as primary antiphospholipid syndrome (APS) ${ }^{(1)}$. The ocular vascular damage is described in the literature and may reveal the syndrome. The diagnosis is important because this disease, which generally affects young people, may endanger ocular and vital prognosis ${ }^{(2)}$. Neovascular glaucoma is a secondary glaucoma with poor prognosis which follows ischemic retinal disorders in the majority of cases. Controversy exists among the authors about the prevalence of antiphospholipid syndrome in retinal vascular occlusions. Herein, we report a case with neovascular glaucoma secondary to ischemic central retinal vein occlusion associated to antiphospholipid antibodies in a young patient.

\section{Case report}

A 34-year-old healthy white man presented with a sudden unilateral loss of vision in his left eye that lasted three weeks. In his ocular history there was an ocular hypertension finding with intraocular pressure (IOP) ranges from 20 to $22 \mathrm{mmHg}$ in both eyes. He had history of a medical evaluation for mild constitutional leucopenia as well. A screening eye examination found $20 / 20$ visual acuity OD and 20/40 OS. The anterior segment was normal in both eyes. Results of a dilated ophthalmoscopic examination revealed a cup/disc ratio of 0.2 with normal funds in OD and in OS cup/disc ratio of 0.5 , retinal vascular occlusion with macular edema and a superior paramacular coriorretinitis scar. Fluorescein angiography supported the ophthalmoscopic findings. Treatment included 3 sessions of argon laser photocoagulation to the region of retinal nonperfusion and a single intravitreal injection of triamcinolone acetonide $(4 \mathrm{mg} / 0.1 \mathrm{ml})$ for the macular edema in the left eye. On follow-up 2 months later, visual acuity returned to $20 / 20 \mathrm{OU}$ and IOP increased up to $28 \mathrm{mmHg}$ in OD and $48 \mathrm{mmHg}$ in OS, but it was controlled with timolol in OD and fixed combination dorzolamidetimolol in OE.

An antiphospholipid syndrome was discovered during etiological check-up with a mutation of Leiden $\mathrm{V}$ factor, but the clinician considered the associated risk insufficient on its own to justify long term anticoagulation.

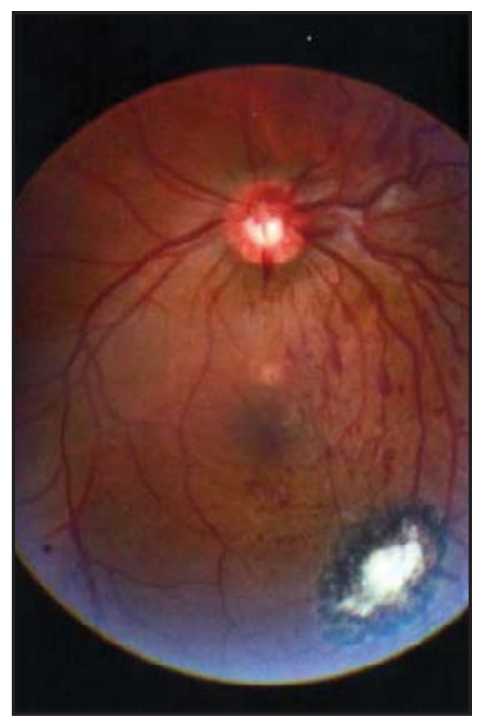

Figure 1: Retinography showing the recurrence of retinal vein occlusion in the left eye

After 18 months the patient presented another sudden unilateral loss of vision in his left eye, with 20/ 800 best corrected visual acuity. Ischemic central retinal vein occlusion (Figure 1) was diagnosed and the eye had undergone full scatter panretinal photocoagulation.

The patient started long term anticoagulation. After three months slitlamp examination revealed 360-degree iris neovascularization and gonioscopy disclosed near total synechial angle closure. IOP was $40 \mathrm{~mm} \mathrm{Hg}$ on timolol and acetazolamide $250 \mathrm{mg}$ every 6 hours, atropine and steroid drops. So, a filtering surgery was done successfully in OS. After 2 years of follow up the vision was unchanged at 20/800 temporal, iris neovascularization remained stable. However, angle configuration remained unchanged with synechial angle closure in most of the circumference and IOP was $18 \mathrm{~mm} \mathrm{Hg}$ with a fixed combination dorzolamide-timolol in OE.

\section{Discussion}

Antiphospholipid syndrome (APS) is an autoimmune disease characterized by presence of antiphospholipid antibodies together with one of the following clinical manifestations: venous and/or arterial thrombosis and repetitive fetal loss. Each year, a total of 35,000 newly recognized APS cases associated with thrombosis are recorded in young population in the USA $^{(3)}$. In most cases, central artery or vein occlusions are due to atherosclerosis. However, other etiologies must be studied in young patients. According to several studies APS has been detected in $5 \%$ to $33 \%$ of the patients showing a major vascular retinal obstruction. The association of thrombophilia must be considered because 
it increases the risk of thrombotic recurrence ${ }^{(2)}$. The coexistence of both hereditary (factor V Leiden) and acquired (primary APS) was also reported in patients with deep venous thrombosis or arterial thromboses supporting the concept that thromboembolism is a multifactorial disorder ${ }^{(4,5)}$. Factor V Leiden is undoubtedly a risk factor for thrombosis of large veins, but it is not considered for retinal vein occlusions.

Controversy exists among the authors about the prevalence of antiphospholipid syndrome in retinal vascular occlusions. Demirci et al. ${ }^{(6)}$ examined 22 patients with primary APS and found posterior segment abnormalities in 15 patients $(68,2 \%)$ with retinal vascular occlusive disease detected in five patients $(22,7 \%)$. In contrast, Glacet-Bernard et al. ${ }^{(7)}$ reported that only $4(5 \%)$ of 75 patients with retinal vascular disease had undetected antiphospholipid antibodies and suggested that these antibodies did not seem to be a feature of retinal vaso-occlusive disease and especially of retinal vein occlusion. At present, the associated risk is insufficient on its own to justify long term anticoagulation and the testing of all patients with retinal vascular occlusion for factor V Leiden is not recommended. It is interesting to note that the patient in case had a recurrence of the trombotic event with permanent loss of visual function before long term anticoagulation was introduced.

In conclusion, we suggest that it seems important to consider anticoagulation and screening for antiphospholipid syndrome in younger patients with retinal vascular occlusive disease that are free of conventional risk factors such as hypertension, diabetes or hyperlipidemia.

\section{Resumo}

Paciente do sexo masculino, 34 anos de idade, com baixa da acuidade visual recorrente. Fundoscopia e angiofluoresceinografia demonstraram oclusão venosa retiniana grave. Durante pesquisa etiológica diagnosticou-se a síndrome do anticorpo antifosfolípide com mutação do fator $V$ Leiden. $O$ paciente iniciou anticoagulação após o segundo evento oclusivo. Entretanto, evoluiu com quadro de glaucoma neovascular e, apesar do tratamento, o olho afetado teve importante redução da acuidade visual. O objetivo deste relato de caso é demonstrar que uma oclusão vascular retiniana pode ser a manifestação inicial da síndrome do anticorpo antifosfolípide, e a importância de seu diagnóstico, pelo fato de afetar pacientes jovens e por em risco o prognóstico vital e ocular. Esse diagnóstico pode acarretar em anticoagulação contínua ou uso de antiagregantes plaquetários para minimizar os riscos de eventos trombóticos recorrentes.

Descritores: Oclusão da veia retiniana; Síndrome antifosfolipídica; Glaucoma; Relatos de casos

\section{RefERENCES}

1. Zajdenweber ME, Muccioli C, Moraes RT, Logan P, Fernandes BF, Burnier Jr. MN. Localized retinal ischemia as an ocular manifestation of primary antiphospholipid syndrome. Can J Ophthalmol. 2007; 42(3):479-80.

2. Vielpeau I, Le Hello C, Legris A, Salsou E, Lecoq PJ. Retinal vascular occlusion and primary antiphospholipid syndrome. Report of 2 cases. J Fr Ophtalmol. 2001; 24(9):955-60.

3. Suvajac G, Stojanovich L, Milenkovich S. Ocular manifestations in antiphospholipid syndrome. Autoimmun Rev. 2006; 6(6):409-14.

4. Chak M, Wallace GR, Graham EM, Stanford MR. Thrombophilia: genetic polymorphisms and their association with retinal vascular occlusive disease. Br J Ophthalmol. 2001; 85(7):883-6.

5. Durrani OM, Gordon C, Murray PI .Primary anti-phospholipid antibody syndrome (APS): current concepts. Surv Ophthalmol. 2002; 47(3):215-38.

6. Demirci FY, Küçükkaya R, Akarçay K, Kir N, Atamer T, Demirci $\mathrm{H}$, Ongör E. Ocular involvement in primary antiphospholipid syndrome. Int Ophthalmol. 1998; 22(6):323-9.

7. Glacet-Bernard A, Bayani N, Chretien P, Cochard C, Lelong F, Coscas G. Antiphospholipid antibodies in retinal vascular occlusions. Arch Ophthalmol. 1994; 112(6):790-5.

\author{
CORRESPONDENCE: \\ Alinne Maria Camargos da Costa \\ Instituto de Olhos de Belo Horizonte \\ Padre Rolim st, 541 - Santa Efigênia \\ Zip Code 30130-090 - Belo Horizonte - MG \\ Phone: + 55 (31) 3218-3000 \\ Fax: +55 (31) 3218-3001 \\ E-mail: alinnecamargos@gmail.com
}

